\title{
AGO Recommendations for the Diagnosis and Treatment of Patients with Locally Advanced and Metastatic Breast Cancer: Update 2019
}

Marc Thill ${ }^{\mathrm{a}}$ Christian Jackisch ${ }^{\mathrm{b}}$ Wolfgang Janni ${ }^{\mathrm{c}}$ Volkmar Müller $^{\mathrm{d}}$ Ute-Susann Albert ${ }^{\mathrm{e}}$ Ingo Bauerfeind ${ }^{f}$ Jens Blohmer ${ }^{g}$ Wilfried Budach ${ }^{\text {h }}$ Peter Dall ${ }^{i}$ Ingo Diel ${ }^{j}$ Peter A. Fasching ${ }^{k}$ Tanja Fehm ${ }^{\prime}$ Michael Friedrich ${ }^{m}$ Bernd Gerber ${ }^{n}$ Volker Hanf ${ }^{\circ}$ Nadia Harbeck $^{p}$ Jens Huober ${ }^{q}$ Cornelia Kolberg-Liedtke ${ }^{g}$ Hans-Heinrich Kreipe ${ }^{r}$ David Krug $^{\mathrm{s}}$ Thorsten Kühn ${ }^{\mathrm{t}}$ Sherko Kümmel ${ }^{\mathrm{u}}$ Sibylle Loibl ${ }^{v}$ Diana Lüftner ${ }^{\mathrm{w}}$ Michael Patrick Lux ${ }^{x}$ Nicolai Maass ${ }^{y}$ Volker Möbus ${ }^{z}$ Markus Müller-Schimpfle ${ }^{A}$ Christoph Mundhenke ${ }^{y} \quad$ Ulrike Nitz $^{B}$ Kerstin Rhiem ${ }^{C}$ Achim Rody ${ }^{D}$ Marcus Schmidt ${ }^{\mathrm{E}}$ Andreas Schneeweiss ${ }^{F}$ Florian Schütz ${ }^{G}$ Hans-Peter Sinn ${ }^{H}$ Christine Solbach ${ }^{1}$ Erich-Franz Solomayer ${ }^{J}$ Elmar Stickeler ${ }^{\mathrm{K}}$ Christoph Thomssen ${ }^{\mathrm{L}}$ Michael Untch ${ }^{\mathrm{M}}$ Frederik Wenz $^{N}$ Isabell Witzel ${ }^{d}$ Achim Wöckel $^{O}$ Nina Ditsch $^{p}$

${ }^{a}$ Klinik für Gynäkologie und Gynäkologische Onkologie, Agaplesion Markus Krankenhaus, Frankfurt/Main, Germany; ${ }^{b}$ Klinik für Gynäkologie und Geburtshilfe, Sana Klinikum Offenbach, Offenbach, Germany; ${ }^{c}$ Klinik für Gynäkologie und Geburtshilfe, Universitätsklinikum Ulm, Ulm, Germany; ${ }^{d}$ Klinik und Poliklinik für Gynäkologie,

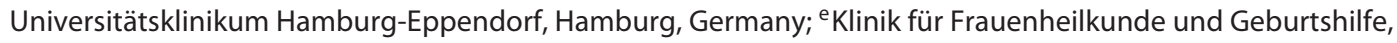
Klinikum Kassel, Kassel, Germany; ${ }^{\mathrm{f}}$ Frauenklinik, Klinikum Landshut, Landshut, Germany; ${ }^{9}$ Klinik für Gynäkologie mit Brustzentrum der Charité, Berlin, Germany; ${ }^{\text {h }}$ Strahlentherapie, Radiologie Düsseldorf, Universitätsklinikum Düsseldorf, Düsseldorf, Germany; ${ }^{i}$ Frauenklinik Städtisches Klinikum Lüneburg, Lüneburg, Germany; ${ }^{j}$ Praxisklinik

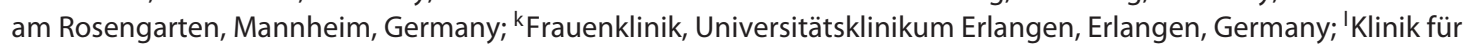
Gynäkologie und Geburtshilfe Universitätsklinikum Düsseldorf, Düsseldorf, Germany; ${ }^{\mathrm{m}}$ Klinik für Frauenheilkunde und Geburtshilfe Helios Klinikum Krefeld, Krefeld, Germany; ${ }^{n}$ Universitätsfrauenklinik am Klinikum Südstadt,

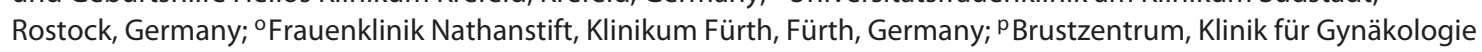
und Geburtshilfe, Klinikum der Ludwig-Maximilians-Universität, Munich, Germany; ${ }^{9}$ Klinik für Gynäkologie und Geburtshilfe, Universitätsklinikum Ulm, Ulm, Germany; ' ${ }^{\prime}$ nstitut für Pathologie, Medizinische Hochschule Hannover, Hannover, Germany; ${ }^{5}$ Klinik für Strahlentherapie, Universitätsklinikum Schleswig-Holstein, Campus

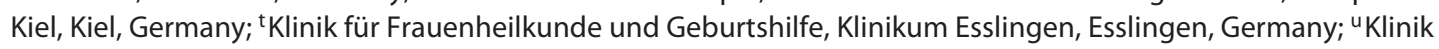
für Senologie, Kliniken Essen Mitte, Essen, Germany; vGerman Breast Group Forschungs GmbH, Neu-Isenburg, Germany; ${ }^{\text {w} M e d i z i n i s c h e ~ K l i n i k ~ m i t ~ S c h w e r p u n k t ~ H a ̈ m a t o l o g i e ~ u n d ~ O n k o l o g i e, ~ C h a r i t e ́, ~ B e r l i n, ~ G e r m a n y ; ~}{ }^{{ }^{*} K l i n i k}$

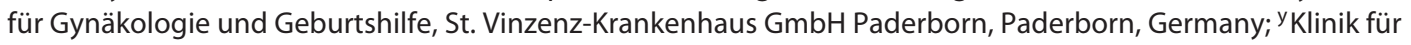
Gynäkologie und Geburtshilfe, Universitätsklinikum Schleswig-Holstein, Campus Kiel, Kiel, Germany; ${ }^{\mathrm{Z} K l i n i k ~ f u ̈ r}$ Gynäkologie und Geburtshilfe, Klinikum Frankfurt Höchst GmbH, Frankfurt/Main, Germany; ${ }^{A}$ Klinik für Radiologie, Neuroradiologie und Nuklearmedizin, Klinikum Frankfurt Höchst GmbH, Frankfurt/Main, Germany; ${ }^{B}$ Senologie, Evangelisches Krankenhaus Bethesda, Mönchengladbach, Germany; ${ }^{C}$ Zentrum Familiärer Brust- und Eierstockkrebs, Universitätsklinikum Köln, Köln, Germany; ${ }^{D}$ Klinik für Gynäkologie und Geburtshilfe, Universitätsklinikum SchleswigHolstein, Campus Lübeck, Lübeck, Germany; ${ }^{E}$ Klinik und Poliklinik für Geburtshilfe und Frauengesundheit der Johannes-Gutenberg-Universität Mainz, Mainz, Germany; ${ }^{F}$ Gynäkologische Onkologie, Universitätsklinikum Heidelberg, Heidelberg, Germany; ${ }^{G}$ Klinik für Gynäkologie und Geburtshilfe, Universitätsklinikum Heidelberg, Heidelberg, Germany; ${ }^{H}$ Sektion Gynäkopathologie, Pathologisches Institut, Heidelberg, Germany; 'Klinik für Frauenheilkunde und Geburtshilfe, Universitätsklinikum Frankfurt, Frankfurt/Main, Germany; ${ }^{J}$ Klinik für Frauenheilkunde, Geburtshilfe und Reproduktionsmedizin, Universitätsklinikum des Saarlandes, Homburg/ Saar, Germany; ${ }^{K}$ Klinik für Gynäkologie und Geburtsmedizin, Universitätsklinikum Aachen, Aachen, Germany; LUniversitätsfrauenklinik, Martin-Luther-Universität Halle-Wittenberg, Halle/Saale, Germany; ${ }^{\mathrm{M} K \text { Klinik für }}$ Gynäkologie und Geburtshilfe, Helios Klinikum Berlin-Buch, Berlin, Germany; NUniversitätsklinikum Freiburg, Freiburg, Germany; ${ }^{\circ}$ Klinik für Gynäkologie und Geburtshilfe, Universitätsklinikum Würzburg, Würzburg, Germany

\section{KARGER}

(C) 2019 S. Karger AG, Basel

E-Mail karger@karger.com

www.karger.com/brc
PD Dr. Marc Thill

Klinik für Gynäkologie und Gynäkologische Onkologie

Agaplesion Markus Krankenhaus, Wilhelm-Epstein-Strasse 4

DE-60431 Frankfurt am Main (Germany)

E-Mail marc.thill@fdk.info 


\section{Keywords}

Early and metastatic breast cancer - Oxford level of evidence - AGO grades of recommendation - Bone health . Locoregional recurrence - Therapy

\section{Abstract}

Every year the Breast Committee of the Arbeitsgemeinschaft Gynäkologische Onkologie (German Gynecological Oncology Group, AGO), a group of gynecological oncologists specialized in breast cancer and interdisciplinary members specialized in pathology, radiologic diagnostics, medical oncology, and radiation oncology, prepares and updates evidencebased recommendations for the diagnosis and treatment of patients with early and metastatic breast cancer. Every update is performed according to a documented rule-fixed algorithm, by thoroughly reviewing and scoring the recent publications for their scientific validity and clinical relevance. This current publication presents the 2019 update on the recommendations for metastatic breast cancer.

(c) 2019 S. Karger AG, Basel

\section{Introduction}

For the last 17 years, the Breast Committee of the Arbeitsgemeinschaft Gynäkologische Onkologie (German Gynecological Oncology Group, AGO) has been preparing and updating evidence-based recommendations for the diagnosis and treatment of patients with early and metastatic breast cancer (MBC). The AGO Breast Committee consists of gynecological oncologists specialized in breast cancer and interdisciplinary members specialized in pathology, radiologic diagnostics, medical oncology, and radiation oncology. This update has been performed according to a documented rule-fixed algorithm, by thoroughly reviewing and scoring chapter by chapter the recent publications for their scientific validity (Oxford level of evidence [LoE], www.cebm.net) [1] and clinical relevance (AGO grades of recommendation; Table 1). We herewith present the 2019 update; the full version of the updated slide set is available online as a PDF file in both English and German [2]. Moreover, a special version for patients is also available at www.ago-online.de.

\section{Bone Health and Osteooncology}

\section{Bone Metastasis}

Osteoclast-inhibiting therapy, including denosumab and bisphosphonates, for reducing the risk of skeletal complications is the standard treatment for breast cancer patients with bone metastases. The approved schedule for denosumab (120 mg subcutaneously [s.c.]) is every 3-4
Table 1. AGO grades of recommendation

++ This investigation or therapeutic intervention is highly beneficial for patients, can be recommended without restrictions, and should be performed

$+\quad$ This investigation or therapeutic intervention is of limited benefit for patients and can be performed

+/- This investigation or therapeutic intervention has not shown benefit for patients and may be performed only in individual cases; according to current knowledge, a general recommendation cannot be given

- This investigation or therapeutic intervention can be of disadvantage for patients and might not be performed

-/- This investigation or therapeutic intervention is of clear disadvantage for patients and should be avoided or omitted in any case

weeks. Since the use of zoledronic acid every 12 weeks (q12w) compared with the standard dosing interval of every 4 weeks $(\mathrm{q} 4 \mathrm{w})$ was associated with equal efficacy, the administration of zoledronic acid $\mathrm{q} 12 \mathrm{w}(\operatorname{LoE} 1 \mathrm{a} / \mathrm{A} /$ AGO ++) should be preferred over zoledronic acid q4w $(\mathrm{LoE} 1 \mathrm{a} / \mathrm{A} / \mathrm{AGO}+)$. As a new rare side effect, inflammatory eye reactions with bisphosphonates have been reported [3]. Based on these observations, patients with eye problems should be referred to an ophthalmologist (LoE 4). Osteoclast-inhibiting therapies alone are not sufficient to overcome pain associated with bone metastases ( $\mathrm{LoE}$ 5/D/AGO -). Therefore, additional pain management is mandatory, including radiotherapy and analgesic drugs [4]. Radiotherapy can be combined with hyperthermia to increase the efficacy of treatment ( $\mathrm{LoE} 2 \mathrm{~b} / \mathrm{B} / \mathrm{AGO}+/-$ ) [5]. The measurement of bone resorption markers to monitor therapy response is not recommended due to conflicting results (LoE 5/D/AGO -) [4].

\section{Adjuvant Therapy}

Both clodronate and aminobisphosphonates may be employed for improvement of prognosis among postmenopausal patients with breast cancer (LoE 1a/A/ AGO +). Evidence regarding the adjuvant use of denosumab, however, is limited. The ABCSG-18 trial has demonstrated a significant improvement in disease-free survival (DFS) in association with application of denosumab $60 \mathrm{mg}$ s.c. $(n=1,712)$ versus placebo $(n=1,713) \mathrm{q} 6$ months during aromatase inhibitor therapy (hazard ratio [HR] 0.823; 95\% confidence interval [CI] 0.69-0.98, Cox $p=0.026)$ after a median follow-up of 72 months. With denosumab, DFS was $89.2 \%$ (95\% CI 87.6-90.7) at 5 years and $80.6 \%(78.1-83.1)$ at 8 years of follow-up compared to $87.3 \%(85.7-89.0)$ at 5 years and $77.5 \%(74.8-80.2)$ at 8 years for patients who received placebo [6] (Fig. 1). 
Fig. 1. Adjuvant bone-targeted therapy for improvement of prognosis.

\begin{tabular}{|c|c|c|c|c|}
\hline 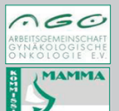 & \multicolumn{4}{|c|}{$\begin{array}{c}\text { Adjuvant Bone Targeted Therapy for } \\
\text { Improvement of Prognosis }\end{array}$} \\
\hline \multirow{9}{*}{$\begin{array}{l}\text { OAGO e.V. } \\
\text { in der DGGG e.V. } \\
\text { sovie } \\
\text { in der DKG e.V. } \\
\text { Guidelines Breast } \\
\text { Version } 2019.1\end{array}$} & \multirow[b]{3}{*}{ - Clodronate (oral) } & \multicolumn{3}{|c|}{ Oxford } \\
\hline & & LoE & GR & AGO \\
\hline & & & & \\
\hline & - Postmenopausal patients & 1a & A & + \\
\hline & Aminemisopausar patients & Ia & B & $+/-$ \\
\hline & Ailing & & & \\
\hline & - Premenopausal patients & 1a & B & $+/-$ \\
\hline & - Denosumab $(6$ x $120 \mathrm{mg} / 3-4 \mathrm{w}+14$ × $120 \mathrm{mg} / 3 \mathrm{~m}$ & & & \\
\hline & $\begin{array}{l}\text {. Postmenopausal patients Stage II and III } \\
\text {. Denosumab }(60 \mathrm{mg} \text { s.c. } 96 \mathrm{~m})\end{array}$ & 1b & B & - \\
\hline IrAREN & - Postmenopausal patients undergoing Al therapy & $1 b^{a}$ & B & $+/-$ \\
\hline
\end{tabular}

Fig. 2. Surgery of chest wall recurrence after mastectomy/axillary recurrence.

\begin{tabular}{|c|c|c|c|c|}
\hline 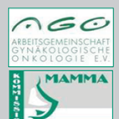 & \multicolumn{4}{|c|}{$\begin{array}{c}\text { Chest-Wall Recurrence after Mastectomy / } \\
\text { Axillary Recurrence - Surgery }\end{array}$} \\
\hline \multirow{6}{*}{$\begin{array}{l}\text {-AGO e.V. } \\
\text { in der DGGG e.V. } \\
\text { sowie } \\
\text { in der DKG e.V. } \\
\text { Guidelines Breast } \\
\text { Version } 2019.1\end{array}$} & \multicolumn{4}{|c|}{ Oxford } \\
\hline & \multirow{4}{*}{$\begin{array}{l}\text { - Curative situation: RO-resection (including deeper } \\
\text { parts of the chest wall in selected cases: HR pos, } \\
\text { primary N-) } \\
\text { - Palliative situation: Resection of deep parts of the } \\
\text { chest wall } \\
\text { - Palliative surgery in M1-situation } \\
\text { (e.g. pain, ulceration, psychosocial) }\end{array}$} & & GR & AGO \\
\hline & & $2 b$ & A & ++ \\
\hline & & 5 & D & $+/-$ \\
\hline & & 5 & D & + \\
\hline & - SLNE after prior SLNE if cNO* & $3 b$ & B & - \\
\hline 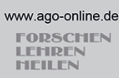 & & & & \\
\hline
\end{tabular}

Due to the exploratory nature of the analysis with regard to its adjuvant effect, application of denosumab $(60 \mathrm{mg}$ s.c. q6 months) cannot be recommended (AGO $1 \mathrm{~B}^{\mathrm{a}} / \mathrm{B} /$ AGO +/-). Results of the D-Care study among patients with stages II-III suggested no benefit regarding either bone metastases-free, disease-free, or overall survival following treatment with denosumab $(120 \mathrm{mg}$ s.c. monthly $\times 6$, then 3-monthly for up to 5 years) versus placebo [7]. Therefore, given the side effects of denosumab, this schedule cannot be recommended (AGO 1b/B/AGO -).

\section{Bone Health}

Bone health is an important issue for breast cancer patients during follow-up. The risk assessment for osteoporosis should be performed in every patient to identify those eligible for additional measures. Patients treated with aromatase inhibitors or suffering from premature ovarian failure should receive an initial bone mineral density measurement. The only validated method of choice is the dual-energy X-ray absorptiometry test. The intervals of bone mineral density measurements are based on individual risk and treatment $(\mathrm{LoE} 5 / \mathrm{D} / \mathrm{AGO}+)[8-$ 10]. Denosumab and bisphosphonates are the standard treatment for the prevention and therapy of osteoporosis. Recent studies indicate that discontinuation of denosumab may increase the risk of vertebral fractures. Therefore, continuation of treatment with other antiresorptive drugs should be considered [11].

\section{Locoregional Recurrence}

In patients with locoregional relapse, pretherapeutic biopsy to re-assess histology as well as the estrogen receptor (ER), progesterone receptor, and human epidermal growth factor receptor 2 (HER2) status is strongly recom- 
Fig. 3. Endocrine-based treatment options for postmenopausal patients with HER2negative metastatic breast cancer.

\begin{tabular}{|c|c|c|c|c|}
\hline 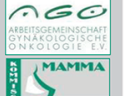 & \multicolumn{4}{|c|}{$\begin{array}{l}\text { Endokrine Based Treatment Option for Postmenopausal } \\
\text { Patients with HER2-Negative Metastatic Breast Cancer }\end{array}$} \\
\hline - AGO e.V. & \multirow{2}{*}{ C CDK4/6-IIhibitor (Abemaciclib, Palbociclib, Ribociclib) } & \multicolumn{2}{|c|}{ Oxford } & \multirow[b]{2}{*}{ AGO } \\
\hline $\begin{array}{l}\text { in dere DOGG e.V. } \\
\text { sowe } \\
\text { in der DKG e.V. }\end{array}$ & & & GR & \\
\hline \multirow{8}{*}{$\begin{array}{l}\text { Guddines rirast } \\
\text { Version } 2019.9\end{array}$} & " + nicht-steroidaler Al & $1 \mathrm{~b}$ & B & \\
\hline & " + Fulvestrant & $1 \mathrm{~b}$ & B & ++ \\
\hline & " Abemaciclib Monotherapie & 3 & c & $+/-$ \\
\hline & " Everolimus & & & \\
\hline & " + Exemestan & $1 \mathrm{~b}$ & A & + \\
\hline & - +Tamoxifen & $2 b$ & B & + \\
\hline & " + Letrozol & $2 b$ & B & $+/-$ \\
\hline & " + Fulvestrant & $2 b^{a}$ & B & + \\
\hline 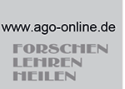 & " CDK4/6i beyond progression & 5 & D & - \\
\hline
\end{tabular}

mended (LoE 3b/B/AGO ++) [12]. Besides well-known clinical and pathological factors and molecular subtypes, obesity is associated with a higher risk of locoregional relapse, a shorter distant recurrence-free survival, and a shorter overall survival, regardless of menopausal status and the time of onset of obesity. This was demonstrated in a recent meta-analysis of 82 studies $(n=213,075)(\mathrm{LoE}$ 1a) [13]. In addition, patients with triple-negative breast cancer (TNBC) and those with HER2-positive breast cancer without adjuvant trastuzumab treatment are at increased risk for locoregional relapse [14, 15]. Clinical consequences, however, of these initial reports remain to be determined.

With regard to surgical options, sentinel lymph node dissection after prior sentinel lymph node biopsy is not indicated, because all the necessary information for consequent therapeutic options will be derived from the tumor biology (LoE 2a/B/AGO -) [16]. Axillary dissection should not be performed in cases with cN0 disease. To achieve R0-resection of the isolated locoregional recurrence (ILRR), deep thoracic wall resection should also be considered in selected cases (primary pN0, late recurrence, hormone receptor-positive primary tumors) [17].

With regard to systemic therapy, the CALOR trial ( $n=162$; median follow-up 9 years) demonstrated a significant benefit for postoperative chemotherapy in patients with fully excised ILRR, particularly in cases with ER-negative disease (LoE 2b/B/AGO +). HRs of a DFS event were 0.29 (95\% CI 0.13-0.67) in patients with ERnegative and 1.07 (95\% CI 0.57-2.00) in patients with ERpositive ILRR ( $p_{\text {interaction }}=0.013$ ). The authors concluded that the final results confirm that chemotherapy benefits patients with resected ER-negative ILRR and does not support the use of chemotherapy for ER-positive ILRR [18] (Fig. 2).
If chemotherapy is indicated, a preoperative approach may be considered. In cases with HER2-positive disease, chemotherapy in combination with HER2-targeted therapy is a reasonable option ( $\mathrm{LoE} 5 / \mathrm{D} / \mathrm{AGO}+$ ). It needs to be emphasized that patients with inoperable locoregional relapse were included in the pertuzumab registration trial CLEOPATRA [19].

In patients with ER-positive locoregional relapse following complete resection (R0), endocrine-based therapy is considered standard. In the case of (re-)recurrent disease in the ipsilateral breast or thoracic wall, the possibility of repeated radiotherapy ( \pm hyperthermia) may be discussed ( $\mathrm{LoE} 3 \mathrm{a} / \mathrm{C} / \mathrm{AGO}+/-$ ). However, these patients seem to have an unfavorable prognosis [20].

\section{Endocrine and Targeted Therapy in MBC}

In women with hormone receptor-positive $\mathrm{MBC}$ (HER2-negative), endocrine-based therapy should be considered first choice, irrespective of menopausal status. Premenopausal women rendered postmenopausal by either gonadotropin-releasing hormone analogues or other means of ovarian function suppression should then be treated like postmenopausal women.

The majority of patients might be candidates for a cyclin-dependent kinase 4/6 (CDK4/6) inhibitor combination therapy. The evidence concerning palbociclib, ribociclib, and abemaciclib has been completed with regard to a variety of patient populations according to therapy line, menopausal status, and endocrine combination partners. Therefore, those combinations therapies are rated with $\mathrm{LoE}$ 1b/B/AGO ++ (Fig. 3). All 3 drugs have been thoroughly investigated in first and further therapy lines in endocrinesensitive and -resistant MBC and demonstrated a homogeneous improvement of progression-free survival with HRs 
Fig. 4. Treatment of triple-negative metastatic breast cancer independent of genomic BRCA $1 / 2$ mutation.

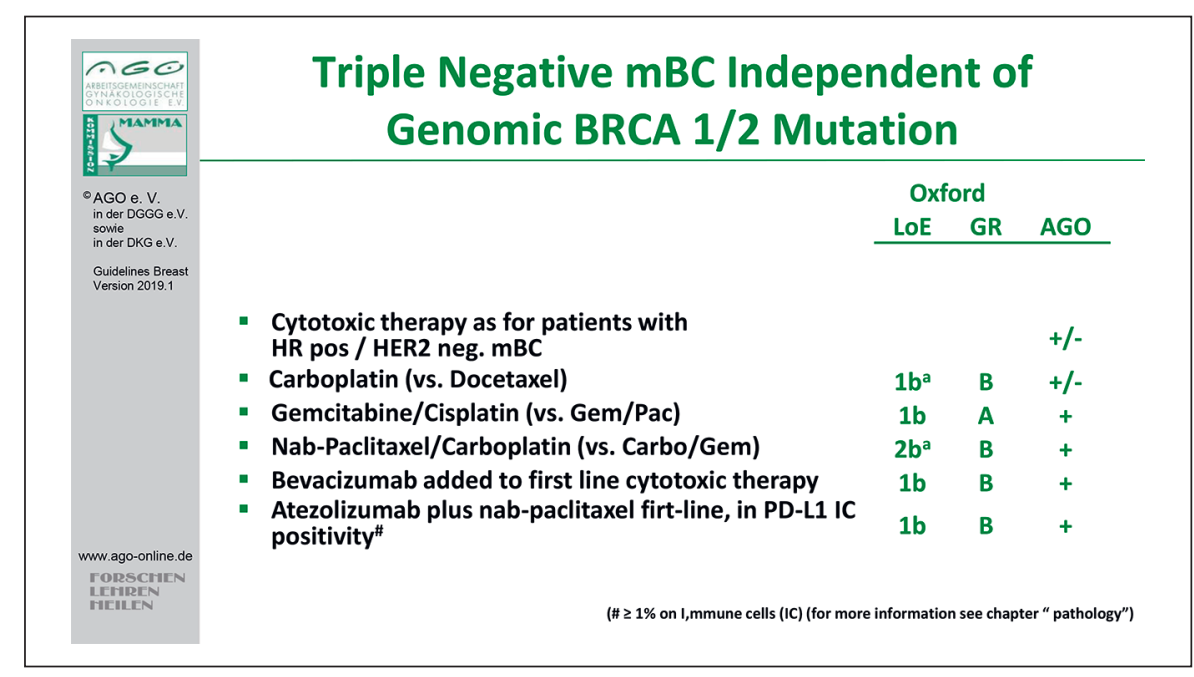

between 0.42 and 0.58 (summarized in $[21,22]$ ). Thus, no subgroup could be identified neither by clinical nor by biomarkers that does not benefit from using a CDK4/6 inhibitor in addition to endocrine therapy [23-28]. Recently, the first overall survival data were published from the PALOMA-3 trial. Formally, the difference was not statistically significant; however, there was a trend towards better overall survival with the CDK4/6 inhibitor (HR 0.8; 95\% CI 0.64-1.03) [29]. This report on overall survival had no influence on the current recommendations.

Patients with hormone receptor-positive breast cancer carrying a germline $B R C A$ mutation might be candidates for poly (ADP-ribose) polymerase (PARP) inhibitors. Both confirmatory studies OlympiAD with olaparib [30] and EMBRACA with talazoparib [31] included about $50 \%$ hormone receptor-positive breast cancers and showed a better progression-free survival compared to standard-of-care monochemotherapies.

All other recommendations have not changed and remain valid.

\section{Chemotherapy with or without Targeted Drugs in MBC}

While on treatment for $\mathrm{MBC}$, reevaluation of quality of life, signs and symptoms, and general health status is important $(\mathrm{A} / \mathrm{AGO}++)$. Monochemotherapy is the treatment of choice in slowly progressing disease or if secondary resistance to endocrine therapy arises (LoE $1 \mathrm{~b} / \mathrm{A} /$ $\mathrm{AGO}++)$. In case of disease progression after taxanes or anthracyclines, eribulin ( $\mathrm{LoE} 1 \mathrm{~b} / \mathrm{B} / \mathrm{AGO}+$ ), capecitabine $(\mathrm{LoE} 2 \mathrm{~b} / \mathrm{B} / \mathrm{AGO}++)$, or vinorelbine $(\mathrm{LoE} 2 \mathrm{~b} / \mathrm{B} / \mathrm{AGO}+)$ are recommended. A recent post hoc analysis of the 301 trial in HER2-negative MBC revealed a significant survival benefit for eribulin over capecitabine (HR 0.77; 95\%
CI 0.62-0.97) [32]. In contrast, combination chemotherapy is recommended in case of need of urgent remission or visceral crisis according to the ABC-4 definition [12].

In $\mathrm{MBC}$ treatment, selection is based on ER and/or progesterone receptor and HER2 status either from the primary tumor or from the metastatic site $(\mathrm{AGO}++)$. Evidence from the IMpassion 130 trial recommends the evaluation of the PD-L1 status on immune cells (IC) in TNBC [33]. In total, 451 TNBC patients were exposed in first-line MBC either to nab-paclitaxel or the combination of nab-paclitaxel and the PD-L1 inhibitor atezolizumab. PD-L1 status of IC (IC positive if $\geq 1 \%$ cells stained positive) was a stratification factor. Regarding the intention to treat analysis, the median overall survival was 21.3 months with atezolizumab plus nab-paclitaxel and 17.6 months with placebo plus nab-paclitaxel (HR for death 0.84 ; $95 \%$ CI $0.69-1.02$; $p=0.08$ ); in patients with PDL1-IC-positive tumors, the median overall survival was 25.0 and 15.5 months, respectively (HR 0.62; 95\% CI $0.45-0.86)$. This might be a new option in first-line therapy of MBC (LoE $1 \mathrm{~b} / \mathrm{B} / \mathrm{AGO}+)$ (Fig. 4$)$.

Next to the recommendation for platinum salts in TNBC (LoE 1b/B/AGO +), PARP inhibitors might be a new option in TNBC as well as in endocrine responsive $\mathrm{MBC}$ with associated BRCA germline mutations (gBRCA) [30, 31]. In both trials (OlympiAD, EMBRACA), the PARP inhibitor improved progression-free survival compared to any chemotherapy as "doctors best choice" in HER2-negative MBC with gBRCA mutation. Thus, olaparib (LoE 1b/B/AGO +) or talazoparib (LoE $\mathrm{b} / \mathrm{B} / \mathrm{AGO}+/-$ ) are new treatment options in this setting.

In HER2-positive MBC, taxane-based chemotherapy plus dual blockade of the HER2 receptor by trastuzumab and pertuzumab is recommended as first-line combination. After progression, trastuzumab-emtansine (T-DM1) is recommended for second-line therapy (LoE 1b/A/AGO ++). 


\section{Central Nervous System Metastases}

Metastases to the central nervous system in breast cancer are of high clinical relevance since the incidence has increased to more than $30 \%$ in high-risk groups, such as HER2-positive or triple-negative MBC patients [34]. Despite this high incidence, evidence for breast cancer-specific treatment approaches is very limited. Therefore, the AGO breast group encourages centers to participate in the German registry for breast cancer patients with brain metastases, BMBC [35]. Local therapy is the treatment of choice. This can be performed either as whole-brain irradiation (WBRT) ( $\mathrm{LoE} 2 \mathrm{a} / \mathrm{B} / \mathrm{AGO}+)$, stereotactic radiotherapy (radiosurgery or fractionated stereotactic radiotherapy), or as surgery ( $\mathrm{LoE} 2 \mathrm{~b} / \mathrm{B} / \mathrm{AGO}++)$. In general, outcome is not improved by surgery compared with radiotherapy. The treatment strategy for patients with limited (1-3, in some studies also up to 4) brain metastases is not clearly defined. Indications for surgery could be histological verification or need for immediate decompression. After surgery, radiotherapy of the resection area is recommended (LoE 1b/B/AGO ++) [36]. Adjuvant WBRT does not improve overall survival despite better brain control. Decline in cognitive function was described to be more frequent with the addition of WBRT to stereotactic radiotherapy. Initial treatment with stereotactic radiotherapy and close monitoring is recommended to better preserve cognitive function in patients with newly diagnosed brain metastases $(\mathrm{LoE} 2 \mathrm{~b} / \mathrm{B} / \mathrm{AGO}++)$ [37] and should be even discussed in patients with multiple brain metastases in which WBRT is still standard of care. With the new radiation technique with conformal avoidance of the hippocampal region, preservation of memory possibly can be improved (LoE $2 \mathrm{~b} / \mathrm{C} /$ $\mathrm{AGO}+/-)$ [38]. In the case of local recurrence in the brain, re-irradiation can be discussed ( $\mathrm{LoE} 4 / \mathrm{C} / \mathrm{AGO}+/-$ ).

Systemic therapy in patients with brain metastases in addition to local therapy should be performed as for other metastatic sites. Actual systemic therapy might be continued if the patient has the first diagnosis of brain metastases with stable extracranial disease ( $\mathrm{LoE} 2 \mathrm{c} / \mathrm{C} / \mathrm{AGO}+$ ).

In patients with HER2-positive disease, HER2-directed therapy should be continued if remission of extracranial disease is achieved. Up to now, no newly developed targeted therapy has been able to prove superiority over other cytotoxic agents in the brain. Tyrosine kinase inhibitors (e.g., ONT-380) and new chemotherapeutic options are being investigated in clinical trials.

\section{Specific Sites of Metastases}

Specific sites of breast cancer metastases are liver, lung, pleura, pericardium, peritoneum, bone marrow, or any soft tissue. Other rare localizations like adrenals, ovaries, uterus, stomach, colon, or placenta have also been reported. However, in such rare cases, controlled trials are not feasible, and treatment options must be discussed on an individual basis.

Management of primary stage IV breast cancer should focus primarily on systemic therapy (LoE $2 \mathrm{a} / \mathrm{B} /$ $\mathrm{AGO}++)$. Surgical treatment should be considered on an individual basis as it does not seem to influence overall survival [39]. Only in women with limited metastatic disease and a good response to systemic treatment, surgical procedures at the primary sites as well as at the metastatic site should be considered ( $\mathrm{LoE} 2 \mathrm{~b} / \mathrm{C} / \mathrm{AGO}+$ ) [40-42].

If surgery of the primary tumor is performed in the metastatic setting, local excision or mastectomy should be done resulting in free margins [43]. Axillary surgery is only indicated for bulky disease ( $\mathrm{LoE} 5 / \mathrm{D} / \mathrm{AGO}+/-$ ). Local radiotherapy of the primary tumor can be performed after local surgical treatment according to the indications of the adjuvant setting ( $\mathrm{LoE} 3 \mathrm{a} / \mathrm{C} / \mathrm{AGO}+$ ).

Systemic treatment of metastatic disease is the therapy of choice. Before treatment, metastases should be confirmed by histology, including evaluation of the hormone receptor and HER2 status. Discordance regarding theses markers may occur in up to $45 \%$ of patients and may have an impact on systemic treatment. If surgery for distant metastases is considered, good overall health, oligometastasis, and a long time interval between primary treatment and the occurrence of metastases are favorable factors regarding an improved outcome. Resection of liver metastases is a matter of debate. It may be considered only after histological verification if R0 resection is feasible, if no extrahepatic metastases are present, and if the tumor biology shows an hormone receptor-positive breast cancer responding well to former systemic therapy with a long disease-free interval and $\leq 3$ metastases (LoE $3 a / B / A G O$ +/-) [44, 45]. In HER2-positive disease, the age should be $<50$ years and the metastases smaller than $5 \mathrm{~cm}$. In these individual cases, 5-year survival rates of $18-61 \%$ can be achieved [46-48]. However, case-control studies did not demonstrate a survival benefit by this approach in comparison to systemic treatment alone; therefore, treatment within clinical trials should be preferred $[49,50]$. Other procedures like regional radiotherapy, stereotactic body radiosurgery with volumetric intensity-modulated arc therapy, thermoablation or chemoembolization are also possible options in individual cases ( $\mathrm{LoE} 3 \mathrm{~b} / \mathrm{C} / \mathrm{AGO}+/-$ ) $[51,52]$.

For patients with lung metastases, the LoE for a curative approach is low, but some patients might benefit from a resection of metastases followed by appropriate systemic treatment $[53,54]$. In accordance with the treatment of liver metastases, resection of lung metastases should only be performed if $\mathrm{R} 0$ resection is feasi- 
ble and histological verification was done (fine-needle aspiration with computed tomography guidance or transbronchial needle aspiration) (LoE 3a/B/AGO +). The timing of any local intervention may be critical; resection before progression is associated with a better outcome.

About $10 \%$ of all breast cancer patients develop malignant pleural effusion (MPE). In almost $50 \%$ of MPE cases, it is the first sign of metastatic disease, resulting in dyspnea and reduced subjective well-being. It should be treated in symptomatic cases. To control MPE, thoracoscopy with talcum pleurodesis ( $\mathrm{LoE} 1 \mathrm{a} / \mathrm{B} / \mathrm{AGO}+$ ) or povidone-iodine (20 mL of a $10 \%$ solution) ( $\mathrm{LoE}$ 1b/B/AGO +), i.e., video-assisted thoracoscopy (LoE $1 \mathrm{~b} / \mathrm{B} / \mathrm{AGO}++)$, or continuous pleural drainage with indwelling pleural catheters $(\mathrm{LoE} / \mathrm{B} / \mathrm{AGO}++)$ are options of choice. Some cohort studies and one small randomized trial demonstrated a higher efficacy and more activities at 30 days in continuous drainage compared to pleurodesis [55-59]. More rarely, other sclerosing agents are used (bleomycin, doxycycline, and mitoxantrone) [60]. If the expected life span is limited, the less invasive procedure should be considered. Overall, 3\% of breast cancer patients will suffer from malignant ascites. Management of ascites takes place in the context of palliative care and aims at improving the quality of life of these patients. Patients with symptomatic ascites should undergo drainage (LoE 4/D/AGO ++). Local antibody therapy with catumaxomab remains not recommended [61].

Malignant pericardial effusion and cardiac tamponade remain rare metastatic locations in patients with breast cancer. In symptomatic patients, drainage and pericardial fenestration are probably the treatment options of choice (LoE 3b/B/AGO ++). For individual patients, video-assisted thoracoscopy or ultrasound-guided puncture with instillation of bleomycin, cisplatin, mitomycin C, or mitoxantrone, or bevacizumab may be an alternative [62-64]. A retrospective analysis suggests benefit from the combination of systemic treatment and pericardial drainage $(\mathrm{LoE} 4 / \mathrm{C} / \mathrm{AGO}++)[65,66]$. It has been reported that aggressive combination treatment regimens were effective, since most patients showed improved marrow function after chemotherapy, and prolonged survival could be possible. However, in most cases, well-tolerated single-agent intravenous weekly treatment (anthracyclines, paclitaxel) or oral capecitabine should be given in order to overcome myelosuppression without endangering the patient's well-being ( $\mathrm{LoE} 4 / \mathrm{D} / \mathrm{AGO}++$ ). In HER2positive patients, anti-HER2 treatment should be added $(\mathrm{LoE} 4 / \mathrm{D} / \mathrm{AGO}++)[67,68]$. Although endocrine therapy may be feasible in some cases, the urgent need for remission in this life-threatening situation should be taken into account.

\section{Breast Cancer - Supportive Care and Side Effect Management}

Optimal side effect management and supportive care is a major contributor to the overall risk/benefit balance associated with oncological therapies. This chapter of the AGO recommendations details aspects that are particularly relevant for treatment of breast cancer patients and is based on the most recent version of the $\mathrm{S} 3$ guidelines [9] and other international guidelines, such as ESMO, wherever available.

Chemotherapy can lead to reactivation of hepatitis B in carriers [69]. Before the start of chemotherapy, screening for hepatitis $B$ (HBsAG, anti-HBC) should therefore be performed in all patients ( $\mathrm{LoE} 2 \mathrm{c} / \mathrm{B} / \mathrm{AGO}+$ ). If one of the tests is positive, HBV DNA needs to be determined. In case of HBV DNA detection, virustatic therapy needs to be initiated ( $\mathrm{LoE} \mathrm{b} / \mathrm{A} / \mathrm{AGO}++)$.

For prevention of chemotherapy-induced alopecia, scalp cooling may be used ( $\mathrm{LoE} 1 \mathrm{~b}$ AGO +/-). A metaanalysis reported a relative reduction of alopecia by $43 \%$ (RR 0.57; 95\% CI 0.45-0.72; $p<0.00001$ ) [70]. Scalp metastases are quite rare $(0.61 \%)$ and do occur even without scalp cooling $(0.41 \%$; difference $p=0.43)$ [71].

T-DM1 in the postneoadjuvant setting causes peripheral neuropathy (LoE $1 \mathrm{~b} / \mathrm{A})$. Thus, in patients pretreated with taxanes, continuing measures for neuropathy prevention, such as compression gloves ( $\mathrm{LoE} 2 \mathrm{~b} / \mathrm{B} / \mathrm{AGO}+$ ) or tactile stimulation ( $\mathrm{LoE} 5 / \mathrm{D} / \mathrm{AGO}+$ ), are very important under subsequent T-DM1.

Detailed and practical management information for new drugs, such as CDK4/6 inhibitors or immunotherapy, can be found in the respective package inserts which are regularly updated.

\section{Palliative Care}

It is well accepted that MBC is incurable but treatable. Early introduction of palliative care concurrent with active treatment is important to improve symptoms and quality of life. Furthermore, discussions about patient preferences at the end of life should begin early in the course of metastatic disease $[12,72]$.

\section{Disclosure Statement}

The conflict of interest statements of all authors with conflicts of interest can be found in the supplementary material (see www. karger.com/doi/10.1159/000500999). 


\section{References}

1 CEBM, Centre for Evidence-Based Medicine. Available from: www.cebm.net.

2 AGO, Arbeitsgemeinschaft Gynäkologische Onkologie e.V. Available from: www.ago-online.de.

3 Clark EM, Durup D. Inflammatory eye reactions with bisphosphonates and other osteoporosis medications: what are the risks? Ther Adv Musculoskelet Dis. 2015 Feb;7(1):11-6.

4 Van Poznak C, Somerfield MR, Barlow WE, Biermann JS, Bosserman LD, Clemons MJ, et al. Role of Bone-Modifying Agents in Metastatic Breast Cancer: An American Society of Clinical Oncology-Cancer Care Ontario Focused Guideline Update. J Clin Oncol. 2017 Dec;35(35):3978-86.

5 Chi MS, Yang KL, Chang YC, Ko HL, Lin YH, Huang SC, et al. Comparing the effectiveness of combined external beam radiation and hyperthermia versus external beam radiation alone in treating patients with painful bony metastases: a phase 3 prospective, randomized, controlled trial. Int J Radiat Oncol Biol Phys. 2018 Jan;100(1):78-87.

6 Gnant M, Pfeiler G, Steger GG, Egle D, Greil R, Fitzal F, et al.; Austrian Breast and Colorectal Cancer Study Group. Adjuvant denosumab in postmenopausal patients with hormone receptor-positive breast cancer (ABCSG-18): disease-free survival results from a randomised, double-blind, placebo-controlled, phase 3 trial. Lancet Oncol. 2019 Mar;20(3):339-51.

7 Coleman RE, Finkelstein D, Barrios CH, Martin M, Iwata H, Glaspy JA, et al. Adjuvant denosumab in early breast cancer: First results from the international multicenter randomized phase III placebo controlled D-CARE study. J Clin Oncol. 2018 May;36(15 suppl):501-501.

8 Hadji P, Coleman RE, Wilson C, Powles TJ, Clézardin P, Aapro M, et al. Adjuvant bisphosphonates in early breast cancer: consensus guidance for clinical practice from a European Panel. Ann Oncol. 2016 Mar;27(3):379-90.

9 Leitlinienprogramm Onkologie. Deutsche Krebsgesellschaft, Deutsche Krebshilfe, AWMF Supportive Therapie bei onkologischen PatientInnen - Langversion 1.1, 2017, AWMF Registernummer: 032/054OL [cited 2018 Jan 18]. Available from: http:// leitlinienprogrammonkologie.de/Supportive-Therapie.95.0.html.

10 Coleman R, Body JJ, Aapro M, Hadji P, Herrstedt J; ESMO Guidelines Working Group. Bone health in cancer patients: ESMO Clinical Practice Guidelines. Ann Oncol. 2014 Sep;25 Suppl 3:iii124-37.

11 Chapurlat R. Effects and management of denosumab discontinuation. Joint Bone Spine. 2018 Oct;85(5):515-7.

12 Cardoso F, Senkus E, Costa A, Papadopoulos E, Aapro M, André F, et al. 4th ESO-ESMO International Consensus Guidelines for Advanced Breast Cancer (ABC 4). Ann Oncol. 2018 Aug;29(8):1634-57.

13 Chan DS, Vieira AR, Aune D, Bandera EV, Greenwood DC, McTiernan A, et al. Body mass index and survival in women with breast cancer-systematic literature review and metaanalysis of 82 follow-up studies. Ann Oncol. 2014 Oct;25(10):1901-14.
14 Cancello G, Maisonneuve P, Rotmensz N, Viale G, Mastropasqua MG, Pruneri G, et al. Prognosis in women with small (T1mic,T1a,T1b) node-negative operable breast cancer by immunohistochemically selected subtypes. Breast Cancer Res Treat. 2011 Jun;127(3):713-20.

15 Jwa E, Shin KH, Kim JY, Park YH, Jung SY, Lee ES, et al. Locoregional Recurrence by Tumor Biology in Breast Cancer Patients after Preoperative Chemotherapy and Breast Conservation Treatment. Cancer Res Treat. 2016 Oct;48(4):1363-72.

16 Ugras S, Matsen C, Eaton A, Stempel M, Morrow M, Cody HS 3rd. Reoperative sentinel lymph node biopsy is feasible for locally recurrent breast cancer, but is it worthwhile? Ann Surg Oncol. 2016 Mar;23(3):744-8.

17 Wakeam E, Acuna SA, Keshavjee S. Chest wall resection for recurrent breast cancer in the modern era: a systematic review and meta-analysis. Ann Surg. 2018 Apr;267(4): 646-55.

18 Wapnir IL, Price KN, Anderson SJ, Robidoux A, Martín M, Nortier JW, et al.; International Breast Cancer Study Group; NRG Oncology, GEICAM Spanish Breast Cancer Group, BOOG Dutch Breast Cancer Trialists' Group; Breast International Group. Efficacy of Chemotherapy for ER-Negative and ER-Positive Isolated Locoregional Recurrence of Breast Cancer: Final Analysis of the CALOR Trial. J Clin Oncol. 2018 Apr;36(11):1073-9.

19 Swain SM, Baselga J, Kim SB, Ro J, Semiglazov V, Campone M, et al.; CLEOPATRA Study Group. Pertuzumab, trastuzumab, and docetaxel in HER2-positive metastatic breast cancer. N Engl J Med. 2015 Feb;372(8):72434.

20 Wapnir IL, Gelber S, Anderson SJ, Mamounas EP, Robidoux A, Martín M, et al.; CALOR trial investigators. Poor Prognosis After Second Locoregional Recurrences in the CALOR Trial. Ann Surg Oncol. 2017 Feb;24(2):398406.

21 Fasching PA, Schneeweiss A, Kolberg HC, Ettl J, Fehm TN, Overkamp F, et al. Translational highlights in breast cancer research and treatment: recent developments with clinical impact. Curr Opin Obstet Gynecol. 2019 Feb; 31(1):67-75.

22 Thill M, Schmidt M. Management of adverse events during cyclin-dependent kinase 4/6 (CDK4/6) inhibitor-based treatment in breast cancer. Ther Adv Med Oncol. 2018 Sep;10: 1758835918793326. Erratum in: Ther Adv Med Oncol. 2018 Dec; 10:1758835918810116.

23 Finn RS, Martin M, Rugo HS, Jones S, Im SA, Gelmon K, et al. Palbociclib and Letrozole in Advanced Breast Cancer. N Engl J Med. 2016 Nov;375(20):1925-36.

24 Finn RS, Crown JP, Lang I, Boer K, Bondarenko IM, Kulyk SO, et al. The cyclin-dependent kinase 4/6 inhibitor palbociclib in combination with letrozole versus letrozole alone as first-line treatment of oestrogen receptorpositive, HER2-negative, advanced breast cancer (PALOMA-1/TRIO-18): a randomised phase 2 study. Lancet Oncol. 2015 Jan; 16(1):25-35.
25 Turner NC, Ro J, André F, Loi S, Verma S, Iwata $\mathrm{H}$, et al.; PALOMA3 Study Group. Palbociclib in Hormone-Receptor-Positive Advanced Breast Cancer. N Engl J Med. 2015 Jul; 373(3):209-19.

26 Hortobagyi GN, Stemmer SM, Burris HA, Yap YS, Sonke GS, Paluch-Shimon S, et al. Ribociclib as First-Line Therapy for HR-Positive, Advanced Breast Cancer. N Engl J Med. 2016 Nov;375(18):1738-48.

27 Sledge GW Jr, Toi M, Neven P, Sohn J, Inoue K, Pivot X, et al. MONARCH 2: Abemaciclib in combination with fulvestrant in women with $\mathrm{HR}+/ \mathrm{HER} 2-$ advanced breast cancer who had progressed while receiving endocrine therapy. J Clin Oncol. 2017 Sep;35(25): 2875-84.

28 Slamon DJ, Neven P, Chia S, Fasching PA, De Laurentiis M, Im SA, et al. Phase III Randomized Study of Ribociclib and Fulvestrant in Hormone Receptor-Positive, $\mathrm{Hu}$ man Epidermal Growth Factor Receptor 2-Negative Advanced Breast Cancer: MONALEESA-3. J Clin Oncol. 2018 Aug; 36(24):2465-72.

29 Turner NC, Slamon DJ, Ro J, Bondarenko I, Im SA, Masuda N, et al. Overall Survival with Palbociclib and Fulvestrant in Advanced Breast Cancer. N Engl J Med. 2018 Nov; 379(20):1926-36

30 Robson M, Im SA, Senkus E, Xu B, Domchek SM, Masuda N, et al. Olaparib for Metastatic Breast Cancer in Patients with a Germline BRCA Mutation. N Engl J Med. 2017 Aug; 377(6):523-33.

31 Litton JK, Rugo HS, Ettl J, Hurvitz SA, Gonçalves A, Lee KH, et al. Talazoparib in Patients with Advanced Breast Cancer and a Germline BRCA Mutation. N Engl J Med. 2018 Aug; 379(8):753-63.

32 Pivot X, Im SA, Guo M, Marmé F. Subgroup analysis of patients with HER2-negative metastatic breast cancer in the second-line setting from a phase 3 , open-label, randomized study of eribulin mesilate versus capecitabine. Breast Cancer. 2018 May;25(3): 370-4.

33 Schmid P, Adams S, Rugo HS, Schneeweiss A, Barrios $\mathrm{CH}$, Iwata $\mathrm{H}$, et al.; IMpassion130 Trial Investigators. Atezolizumab and Nab-Paclitaxel in Advanced Triple-Negative Breast Cancer. N Engl J Med. 2018 Nov;379(22): 2108-21.

34 Witzel I, Oliveira-Ferrer L, Pantel K, Müller V, Wikman H. Breast cancer brain metastases: biology and new clinical perspectives. Breast Cancer Res. 2016 Jan;18(1):8.

35 Witzel I, Laakmann E, Weide R, Neunhöffer T, Park-Simon TJ, Schmidt M, et al. Treatment and outcomes of patients in the Brain Metastases in Breast Cancer Network Registry. Eur J Cancer. 2018 Oct;102:1-9.

36 Brown PD, Ballman KV, Cerhan JH, Anderson SK, Carrero XW, Whitton AC, et al. Postoperative stereotactic radiosurgery compared with whole brain radiotherapy for resected metastatic brain disease (NCCTG N107C/ CEC.3): a multicentre, randomised, controlled, phase 3 trial. Lancet Oncol. 2017 Aug; 18(8):1049-60. 
37 Brown A, Asher AL, Ballman K, Farace E, Cerhan J, Anderson K, et al. NCCTG N0574 (Alliance): A phase III randomized trial of whole brain radiation therapy (WBRT) in addition to radiosurgery (SRS) in patients with 1 to 3 brain metastases. J Clin Oncol. 2015 Jan;33(18 suppl):Abstract LBA4.

38 Gondi V, Pugh SL, Tome WA, Caine C, Corn B, Kanner A, et al. Preservation of memory with conformal avoidance of the hippocampal neural stem-cell compartment during whole-brain radiotherapy for brain metastases (RTOG 0933): a phase II multi-institutional trial. J Clin Oncol. 2014 Dec;32(34): 3810-6.

39 Badwe R, Hawaldar R, Nair N, Kaushik R, Parmar V, Siddique S, et al. Locoregional treatment versus no treatment of the primary tumour in metastatic breast cancer: an openlabel randomised controlled trial. Lancet Oncol. 2015 Oct;16(13):1380-8.

40 Soran A, Ozmen V, Ozbas S, Karanlik H, Muslumanoglu M, Igci A, et al. A randomized controlled trial evaluating resection of the primary tumor in women presenting with de novo stage IV breast cancer: Turkish Study (Protocol MF07-01). J Clin Oncol. 2017 May; 34(15 suppl);Abstract 1005.

41 Warschkow R, Güller U, Tarantino I, Cerny T, Schmied BM, Thuerlimann B, et al. Improved Survival After Primary Tumor Surgery in Metastatic Breast Cancer: A Propensity-adjusted, Population-based SEER Trend Analysis. Ann Surg. 2016 Jun;263(6):118898.

42 Yoo TK, Chae BJ, Kim SJ, Lee J, Yoon TI, Lee $\mathrm{SJ}$, et al. Identifying long-term survivors among metastatic breast cancer patients undergoing primary tumor surgery. Breast Cancer Res Treat. 2017 Aug;165(1):109-18.

43 Rapiti E, Verkooijen HM, Vlastos G, Fioretta G, Neyroud-Caspar I, Sappino AP, et al. Complete excision of primary breast tumor improves survival of patients with metastatic breast cancer at diagnosis. J Clin Oncol. 2006 Jun;24(18):2743-9.

44 Howlader M, Heaton N, Rela M. Resection of liver metastases from breast cancer: towards a management guideline. Int J Surg. 2011;9(4): 285-91.

45 Abbott DE, Brouquet A, Mittendorf EA, Andreou A, Meric-Bernstam F, Valero V, et al. Resection of liver metastases from breast cancer: estrogen receptor status and response to chemotherapy before metastasectomy define outcome. Surgery. 2012 May;151(5):710-6.

46 Vertriest C, Berardi G, Tomassini F, Vanden Broucke R, Depypere H, Cocquyt V, et al.; Single Center Experience and Review of the Literature. Resection of single metachronous liver metastases from breast cancer stage I-II yield excellent overall and disease-free survival. Single center experience and review of the literature. Dig Surg. 2015;32(1):52-9.
47 Dittmar Y, Altendorf-Hofmann A, Schüle S, Ardelt M, Dirsch O, Runnebaum IB, et al. Liver resection in selected patients with metastatic breast cancer: a single-centre analysis and review of literature. J Cancer Res Clin Oncol. 2013 Aug;139(8):1317-25.

48 Margonis GA, Buettner S, Sasaki K, Kim Y, Ratti F, Russolillo N, et al. The role of liverdirected surgery in patients with hepatic metastasis from primary breast cancer: a multiinstitutional analysis. HPB (Oxford). 2016 Aug;18(8):700-5.

49 Sadot E, Lee SY, Sofocleous CT, Solomon SB, Gönen M, Kingham TP, et al. Hepatic Resection or Ablation for Isolated Breast Cancer Liver Metastasis: A Case-control Study With Comparison to Medically Treated Patients. Ann Surg. 2016 Jul;264(1):147-54.

50 Fairhurst K, Leopardi L, Satyadas T, Maddern $\mathrm{G}$. The safety and effectiveness of liver resection for breast cancer liver metastases: A systematic review. Breast. 2016 Dec;30:175-84.

51 Hoffmann RT, Jakobs TF, Kubisch $\mathrm{CH}$, Stemmler HJ, Trumm C, Tatsch K, et al. Radiofrequency ablation after selective internal radiation therapy with Yttrium90 microspheres in metastatic liver disease-Is it feasible? Eur J Radiol. 2010 Apr;74(1):199-205.

52 Vogl TJ, Farshid P, Naguib NN, Zangos S. Thermal ablation therapies in patients with breast cancer liver metastases: a review. Eur Radiol. 2013 Mar;23(3):797-804

53 Rashid OM, Takabe K. The evolution of the role of surgery in the management of breast cancer lung metastasis. J Thorac Dis. 2012 Aug;4(4):420-4

54 Tanaka K, Shimizu K, Ohtaki Y, Nakano T, Kamiyoshihara M, Kaira K, et al. Diagnosis and surgical resection of solitary pulmonary nodules in patients with breast cancer. Mol Clin Oncol. 2013 Jan;1(1):117-23.

55 Warren WH, Kalimi R, Khodadadian LM, Kim AW. Management of malignant pleural effusions using the Pleur(x) catheter. Ann Thorac Surg. 2008 Mar;85(3):1049-55.

56 Hak CC, Sivakumar P, Ahmed L. Safety of indwelling pleural catheter use in patients undergoing chemotherapy: a five-year retrospective evaluation. BMC Pulm Med. 2016 Mar; 16:41.

57 MacEachern P, Tremblay A. Pleural controversy: pleurodesis versus indwelling pleural catheters for malignant effusions. Respirology. 2011 Jul;16(5):747-54.

58 Srour N, Amjadi K, Forster A, Aaron S. Management of malignant pleural effusions with indwelling pleural catheters or talc pleurodesis. Can Respir J. 2013 Mar-Apr;20(2):10610.

59 Olden AM, Holloway R. Treatment of malignant pleural effusion: PleuRx catheter or talc pleurodesis? A cost-effectiveness analysis. J Palliat Med. 2010 Jan;13(1):59-65.

60 Demmy TL, Gu L, Burkhalter JE, Toloza EM, D'Amico TA, Sutherland S, et al.; Cancer and Leukemia Group B. Optimal management of malignant pleural effusions (results of CALGB 30102). J Natl Compr Canc Netw. 2012 Aug; 10(8):975-82.
61 Sebastian M, Kuemmel A, Schmidt M, Schmittel A. Catumaxomab: a bispecific trifunctional antibody. Drugs Today (Barc). 2009 Aug;45(8):589-97.

62 El Haddad D, Iliescu C, Yusuf SW, William WN Jr, Khair TH, Song J, et al. Outcomes of Cancer Patients Undergoing Percutaneous Pericardiocentesis for Pericardial Effusion. J Am Coll Cardiol. 2015 Sep;66(10):1119-28.

63 Lestuzzi C, Berretta M, Tomkowski W. 2015 update on the diagnosis and management of neoplastic pericardial disease. Expert Rev Cardiovasc Ther. 2015 Apr;13(4):377-89.

64 Numico G, Cristofano A, Occelli M, Sicuro M, Mozzicafreddo A, Fea E, et al. Prolonged Drainage and Intrapericardial Bleomycin Administration for Cardiac Tamponade Secondary to Cancer-Related Pericardial Effusion. Medicine(Baltimore).2016Apr;95(15):e3273.

65 Çelik S, Lestuzzi C, Cervesato E, Dequanter D, Piotti P, De Biasio M, et al. Systemic chemotherapy in combination with pericardial window has better outcomes in malignant pericardial effusions. J Thorac Cardiovasc Surg. 2014 Nov;148(5):2288-93.

66 Tanaka Y, Fukino S, Oono T, Kodama W, Nishimura K, Hamasaki N. [A Case of Carcinomatous Pericarditis of Breast Cancer Successfully Treated with Intrapericardial Mitomycin C Instillations and Systemic Chemotherapy]. Gan To Kagaku Ryoho. 2016 May; 43(5):609-11

67 Artac M, Koral L, Toy H, Guler T, Boruban MC, Altundag K. Complete response and long-term remission to anti-HER2 combined therapy in a patient with breast cancer presented with bone marrow metastases. J Oncol Pharm Pract. 2014 Apr;20(2):141-5.

68 Kopp HG, Krauss K, Fehm T, Staebler A, Zahm J, Vogel W, et al. Symptomatic bone marrow involvement in breast cancer - clinical presentation, treatment, and prognosis: a single institution review of 22 cases. Anticancer Res. 2011 Nov;31(11):4025-30.

69 Liu Z, Jiang L, Liang G, Song E, Jiang W, Zheng $Y$, et al. Hepatitis B virus reactivation in breast cancer patients undergoing chemotherapy: A review and meta-analysis of prophylaxis management. J Viral Hepat. 2017 Jul; 24(7):561-72.

70 Rugo HS, Voigt J. Scalp Hypothermia for Preventing Alopecia During Chemotherapy. A Systematic Review and Meta-Analysis of Randomized Controlled Trials. Clin Breast Cancer. 2018 Feb;18(1):19-28.

71 Rugo HS, Melin SA, Voigt J. Scalp cooling with adjuvant/neoadjuvant chemotherapy for breast cancer and the risk of scalp metastases: systematic review and meta-analysis. Breast Cancer Res Treat. 2017 Jun;163(2):199-205.

72 Ferrell BR, Temel JS, Temin S, Smith TJ. Integration of Palliative Care into Standard Oncology Care: ASCO Clinical Practice Guideline Update Summary. J Oncol Pract. 2017 Feb;13(2):119-21. 